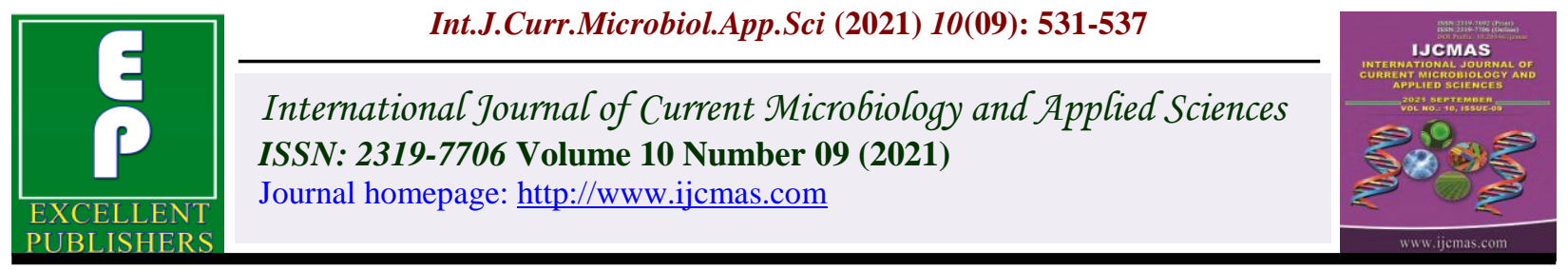

\title{
Evaluation of Genetic Variability, Heritability and Genetic Advance in Advanced Breeding Lines of Wheat (Triticum aestivum L)
}

\author{
Asha Kushwah*, Sanjay Singh, Sushma Tiwari and R. S. Sikarwar
}

Department of Genetics and Plant Breeding, College of Agriculture, Rajmata Vijayaraje Scindia Krishi Vishwa Vidyalaya (RVSKVV), Gwalior, Madhya Pradesh - 474 002, India

*Corresponding author

\section{A B S T R A C T}

Keywords

Triticum aestivum L, King of Cereals, Poaceae family, Wheat grain

Article Info

Accepted:

20 August 2021

Available Online:

10 September 2021
The Present investigation was carried out using 522 advanced breeding lines of wheat genotypes at BISA Farm, Jabalpur during Rabi, 2018-2019 in randomized block design with two replications. Analysis of variance found the significant difference between breeding lines for all the characters were studied. Appropriate variability was obtainable in the advance breeding lines under study for all the characters indicating sufficient genetic variability among the genotypes. Phenotypic coefficient of variation (PCV) was marginally higher than the respective genotypic coefficient of variation (GCV) for all the characters indicating thereby that there is negligible influence on the characters by the environment. GCV was high for grain yield per plant, grain weight per spike, biological yield per plant, number of grains per spike and number of effective tillers per plant. High PCV was observed for grain weight per spike followed by grain weight per plant, biological yield per plant, number of grains per spike, number of effective tillers per plant and length of main spike. High broad sense heritability along with high genetic advance as percentage of mean were obtained for number of non extruded anther per spike, anther extrusion \%, visual score of anther extrusion, biomass per plot and number of productive tillers per plant.

\section{Introduction}

Wheat (Triticum aestivum L.) is the most important cereal crop for the majority of world population and has been described as "King of Cereals". In India it is a second major staple crop after rice and plays a key role in food and nutritional security. It is an allohexaploid with chromosome number $2 \mathrm{n}=6 \mathrm{X}=42$ comprising three genetically related genomes A, B \& D. It belongs to the Poaceae family. It is one of the most vital staple food grain amongst major cereals of the world, occupying $17 \%$ of crop acreage worldwide, feeding about $40 \%$ of the world population and provide $20 \%$ of the protein and total food calories in human nutrition. Wheat originated from South West Asia. It is a highly self-pollinated crop and an 
annual plant having height about 60 to $150 \mathrm{~cm}$ long. Inflorescence of wheat is erect terminal spike of spikelets called as ear or head or spike of grains, flower grouped into 15-20 spikelets arranged alternatively on rachis, each spikelets with 2-6 flowers out of which only 23 flowers are fertile and produce grains. Wheat grain contains 2-3\% germ, 13-17\% bran (outer layers of wheat grain) and 80-85\% mealy endosperm on dry matter basis (Belderok et al., 2000). Wheat Bran is rich in vitamin $B$ and minerals. The endosperm mainly contains food reserves which are needed for growth of the seedling. Endosperm contains fats $(1.5 \%)$ and proteins (13\%), albumins, globulins and the major proteins of the gluten complex glutenins and gliadinsproteins that will form the gluten at dough stage. Globally, wheat (Triticum spp.) is grown in about 220.83 million hectares holding the position of highest acreage among all crops with annual production hovering around 769.31 million tones (USDA, 2020). In India, it is grown in area of 30.55 million hectares with a production of 107.18 million tones and productivity of $3508 \mathrm{~kg} / \mathrm{ha}$. In Madhya Pradesh, it is grown-up in an area of 49 lakh hectare with a production of 125.6 lakh tones, respectively (Anonymous, 2020). Grain yield in wheat is a complex character and is depend on its component traits. For genetic manipulation of grain yield, quality and other characters in wheat, there is a need to examine the nature of genetic variability for the yield related attributes and quality traits. Anther extrusion is a complex trait controlled by many genes. The genetic basis of $\mathrm{AE}$ has mostly been unveiled via conventional mapping studies (Skinnes et al., 2010; Lu et al., 2013; Buerstmayr and Buerstmayr, 2015). Estimation of genotypic coefficient of variation $(\mathrm{GCV})$ and phenotypic coefficient of variation (PCV) helps to choose the potential genotype and heritability along with genetic advance would be more useful tool in predicting the resultant effect for selection of best genotypes for yield. Keeping these things in the view, the present investigation was made to assess genotypes with the objectives, to estimate the variability, heritability and genetic advance for yield and yield components traits in wheat.

\section{Materials and Methods}

Experimental Site: Advanced wheat breeding lines obtained from CIMMYT wheat breeding program will be planted for morphological characterization at BISA farm Jabalpur and the experimental Seasons was rabi 2018-2019. Soil texture of research field was clay loam with $\mathrm{pH}$ 7.6.

The experiment was laid out in randomized block design (RBD) with 2 replications. The recommended package of practices was adopted for raising the healthy crop. Observations for all the traits were recorded on five randomly selected plants of each entry in each replication.

\section{Statistical analysis}

To test the difference among the genotypes, the analysis of variance was worked out separately for each character as per method suggested by fisher (1954) and using standard statistical procedure given by Panse and Sukhatme (1954).

\section{Genotypic and phenotypic variances}

These were calculated as follows:

Genotypic variance $=\left(\sigma^{2} \mathrm{~g}\right)=\left(\mathrm{V}_{\mathrm{g}}-\mathrm{V}_{\mathrm{e}}\right) / \mathrm{r}$

Phenotypic variance $=\left(\sigma^{2} p\right)=\sigma^{2} g+\sigma^{2} e$

Environmental variance $=\left(\sigma^{2} \mathrm{e}\right)=\mathrm{V}_{\mathrm{e}}$

The genotype mean sum of square was tested against error mean sum of square by ' $\mathrm{F}$ ' test $\mathrm{n}_{1}$ 
$(\mathrm{t}-1)$ and $\mathrm{n}_{2}(\mathrm{r}-1)(\mathrm{t}-1)$ degree of freedom both at 0.05 and 0.01 probability levels. Any significant variation was marked as one asterisk 0.05 and two asterisks 0.01 against the corresponding mean square in the analysis of variance table.

\section{Estimation of phenotypic and genotypic coefficients of variation}

The phenotypic and genotypic coefficients of variation in per cent were computed by the following formulae given by Burton (1952).

Phenotypic Coefficient of Variation

$$
\text { PCV \%) }=\frac{\text { Phnotypic SD }}{\text { Mean }} \times 100
$$

Genotypic Coefficient of Variation

$(\mathrm{GCV} \%)=\frac{\text { Genotypic SD }}{\text { Mean }} \times 100$

The PCV and GCV values are ranked as low, medium and high (Shivasubramanian and Menon, 1973) and are mentioned below:

$<10 \%$ - Low

10-20\% - Moderate

$>20 \%$ - High

\section{Heritability (\%)}

The ratio of genetic variance to the total variance, i.e. phenotypic variance is known as heritability. Heritability $(\mathrm{H})$ in broad sense (Lush, 1949) was calculated as:

$\mathrm{H}^{2}(\%)=$ Genotypic variance / Phenotypic variance $\mathrm{X} 100$

Heritability values are categorized as low, moderate and high (Robinson et al., 1949) and are given below:

$<30 \%$ - Low
$30-60 \%$ - Moderate

$>60 \%$ - High

\section{Genetic advance (GA)}

The improvement in the performance of selected lines over the original population is known as genetic advance.

The genetic advance i.e. expected genetic gain from the selection of superior individuals was estimated by the formula suggested by Lush (1949).

Thus, GA = Genotypic variance / phenotypic variance $\mathrm{Xk} . \sigma \mathrm{p}$

Where,

$\sigma p=$ Phenotypic standard deviation

$\mathrm{K}=$ Standard selection differential

Genetic advance was expressed as percentage of mean by using the formula suggested by Johnson et al., (1955).

Genetic advance as percentage of mean

$=\frac{\text { Genetic advance }}{\text { Grand mean }} \times 100$

Genetic advance as percent of mean was classified as low, moderate and high (Johnson et al., 1955) and values are given below:

$<10 \%$ - Low

$10-20 \%$ - Moderate

$>20 \%$ - High

\section{Results and Discussion}

Analysis of variance (ANOVA) table 1 for all the characters viz., days to 50 per cent heading 
(days), days to 50 per cent flowering (days), days to maturity (days), peduncle length $(\mathrm{cm})$, plant height $(\mathrm{cm})$, No. of effective tillers per plant, spike length $(\mathrm{cm})$, No. of spikelets per plant, No. of grains per spike, number of non extruded anthers per spike, anther extrusion $\%$, visual score of anther extrusion, biomass (g), 1000 seed weight (g) and grain yield per plot (g)exposed highly significant mean sum of squares due to genotypes for all the characters studied representing the occurrence of adequate genetic variation amongst all the breeding lines.

The mean sum of squares due to replication was found to be non-significant for all the traits studied,

Table 2. High magnitude of GCV were observed for number of non extruded anther per spike (54.179) followed by visual score of anther extrusion (37.745) anther extrusion \% (33.224) biomass per plot (21.934) and number of productive tillers per plant (20.181).

Low magnitude of GCV observed for days to maturity (4.363) and days to $50 \%$ flowering (5.530).

High magnitude of PCV were observed for number of non extruded anther per spike (54.604) followed by visual score of anther extrusion (41.865), anther extrusion\% (33.485) number of productive tillers (26.361) and biomass per plot (21.995).

Low magnitude of PCV observed for days to maturity (4.454), days to $50 \%$ flowering (5.675) and days to $50 \%$ heading (6.019).

Heritability in broad sense was high for most of the characters studied except number of productive tillers per plant (0.586) and number of spikelets per spike (0.624). The highest heritability were similar observed for two traits i.e. biomass per plot and grain yield per plot (0.994) followed by 1000 grain weight (0.987) and for number of non extruded anther per spike, anther extrusion \% were (0.984). High magnitude of genetic advancement were observed for biomass per plot (378.520) followed by anther extrusion \% (42.092), grain yield per plot (28.731), number of non extruded anthers per spike (25.258) and days to maturity (10.843).

Low magnitude of genetic advancement were observed for spike length (1.464) and number of productive tillers per plant (1.664).

In the present investigation the phenotypic coefficient of variation (PCV) was marginally higher than the respective genotypic coefficient of variation (GCV) for all the characters studied indicating that there is negligible influence on the expression of characters by the environment.

The grain yield per plant depicted highest genotypic coefficient of variation followed by grain weight per spike, biological yield per plant, number of grains per spike and number of effective tillers per plant, while highest phenotypic coefficient of variation (PCV) observed for grain weight per spike.

The magnitude of GCV and PCV were low for days to maturity and protein content, Table 2. Earlier similar finding have been also reported by Yadav et al., (2014), Kumar et al., (2014) and Bhushan et al., (2013).

The heritability estimates in broad sense were quite high for most of the characters indicated that strong genetic nature for all the traits.

The higher heritability implied that selection for most of the traits might be effective in this set of genotypes. Similar findings were also reported by Bhushan et al., (2013) and Nukasani et al., (2013). 
Table.1 Analysis of variance of fifteen traits in wheat lines for Rabi 2019, for Jabalpur, Location

\begin{tabular}{|c|c|c|c|c|c|c|c|c|}
\hline S.No. & Characters & Replication & $\begin{array}{c}\text { Mean sum of } \\
\text { squares treatment }\end{array}$ & Error & Mean & Maximum & Minimum & Range \\
\hline & Degree of Freedom & 1 & 521 & 521 & & & & \\
\hline 1 & Days to $50 \%$ heading & 975.17 & $50.77^{* *}$ & 2.76 & 83.7 & 96.5 & 69.5 & 27 \\
\hline 2 & $\begin{array}{l}\text { Days to } 50 \% \\
\text { flowering }\end{array}$ & 973.24 & $51.29^{* *}$ & 2.58 & 89.2 & 101.5 & 74.5 & 27 \\
\hline 3 & Days to maturity & 979.04 & $60.15^{* *}$ & 2.42 & 123.1 & 135.5 & 108 & 27.5 \\
\hline 4 & Peduncle length $(\mathrm{cm})$ & 11.76 & $12.68^{* *}$ & 2.98 & 14.5 & 24.5 & 8.0 & 16.5 \\
\hline 5 & Plant height (cm) & 20.36 & $65.59^{* *}$ & 9.70 & 92.8 & 105.0 & 73.3 & 31.7 \\
\hline 6 & $\begin{array}{c}\text { Number of } \\
\text { productive tillers }\end{array}$ & 15.69 & $4.65^{* *}$ & 0.99 & 5.4 & 11.5 & 2.5 & 9 \\
\hline 7 & Spike length $(\mathrm{cm})$ & 0.01 & $2.38^{* *}$ & 0.62 & 10.5 & 14.8 & 7.0 & 7.8 \\
\hline 8 & $\begin{array}{l}\text { Number of spikelets } \\
\text { per spike }\end{array}$ & 0.16 & $6.61^{* *}$ & 1.66 & 19.1 & 24.0 & 10.0 & 14 \\
\hline 9 & $\begin{array}{l}\text { Number of grains per } \\
\text { spike }\end{array}$ & 8.46 & $80.99^{* *}$ & 17.92 & 58.2 & 76.5 & 37.5 & 39 \\
\hline 10 & $\begin{array}{l}\text { No. of Non extruded } \\
\text { anthers per spike }\end{array}$ & 75.10 & $309.98^{* *}$ & 12.42 & 22.8 & 57.5 & 7.0 & 50.5 \\
\hline 11 & Anther extrusion \% & 1157.11 & $840.52^{* *}$ & 42.55 & 61.6 & 88.3 & 5.9 & 82.4 \\
\hline 12 & $\begin{array}{l}\text { Visual score of anther } \\
\text { extrusion }\end{array}$ & 15.69 & $5.47^{* *}$ & 0.58 & 3.9 & 9.0 & 2.0 & 7 \\
\hline 13 & Biomass (g) & 378329.38 & $66581.84^{* *}$ & 7298.89 & 848.1 & 1381.5 & 211.5 & 1170 \\
\hline 14 & $\begin{array}{l}\text { Thousand seed } \\
\text { weight }(\mathrm{g})\end{array}$ & 378.44 & $35.87^{* *}$ & 2.25 & 44.9 & 58.2 & 33.4 & 24.8 \\
\hline 15 & Grain yield $(\mathrm{g})$ & 39946.27 & $394.49^{* *}$ & 63.68 & 142.7 & 182.1 & 92.6 & 89.5 \\
\hline
\end{tabular}


Table.2 Genetic variability parameters for yield and its contributing traits in wheat

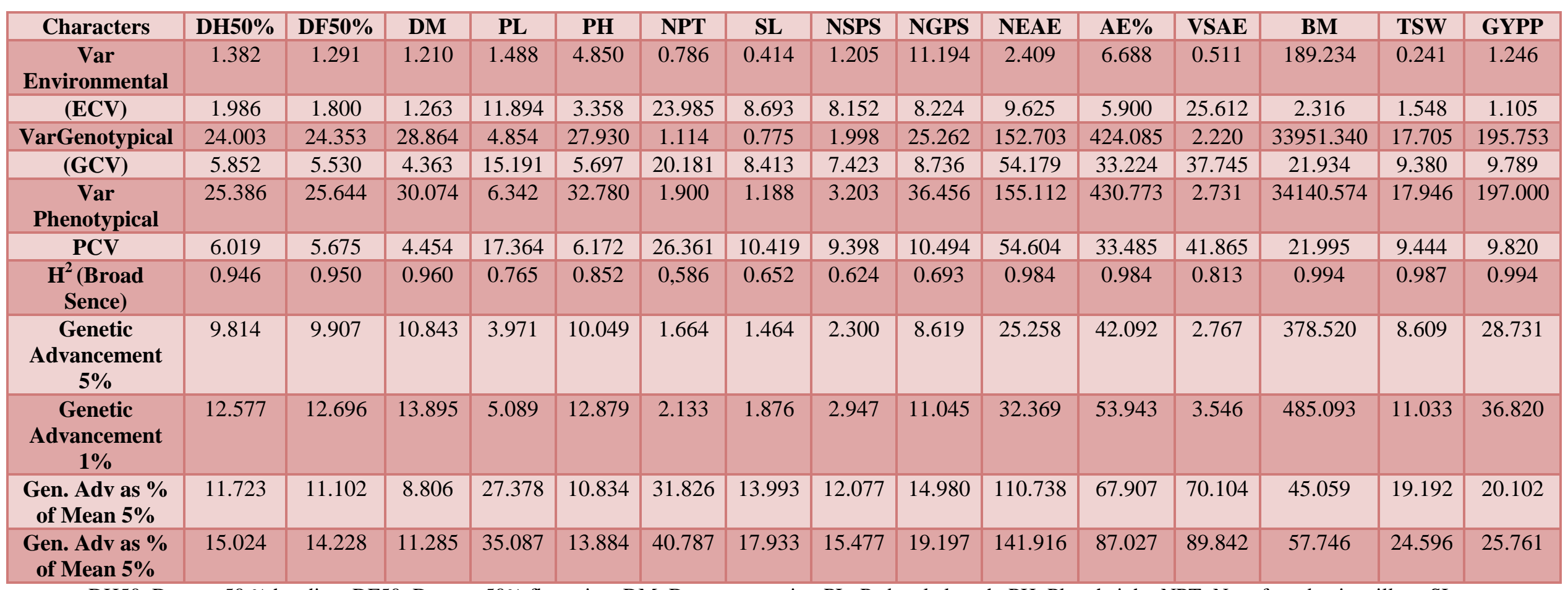

DH50: Days to $50 \%$ heading, DF50: Days to 50\% flowering, DM: Days to maturity, PL: Peduncle length, PH: Plant height, NPT: No. of productive tillers, SL:

Spike length, NSPS: No. of spikelet's per spike, NGPS: No. of grains per spike, NEA: No. of no-extruded anthers per spike, AE \%: Anther extrusion percentage,

Visual_AE: Visual score of anther extrusion, BM: Biomass, GYPP: Grain yield, TSW: Thousand seed weight. 


\section{References}

Anonymous, 2019. Project Director's Report, ICAR-IIWBR, Karnal, Haryana, pp.1-3

Belderok, B., Mesdag, J., Mesdag, H. and Donner, D. A., 2000. Bread-making quality of wheat: a century of breeding in Europe. Springer Science \& Business Media. Pp. 15-20.

Bhushan, B., Bharti, S., Ojha, A., Pandey, M., Gaurav, S. S., Tyagi, B. S. and Singh, G. 2013. Genetic variability, correlation coefficient and path analysis of some quantitative traits in bread wheat. Journal of Wheat Research, 5(1): 21-26.

Buerstmayr, M., \& Buerstmayr, H. (2015). Comparative mapping of quantitative trait loci for Fusarium head blight resistance and anther retention in the winter wheat population Capox Arina. Theoretical and Applied Genetics, 128(8), 1519-1530.

Burton, G. W. 1952. Quantitative inheritance in grasses. Proc. 6th International Grassland Congress, 1: 277-283.

Burton, G. W., 1952. Estimating heritability in tall fescue from replicated clonal material. Agronomy Journal, 45(3), pp. 474-481.

Fisher, R. A. 1954. Statistical methods for research workers. 12th Edition, Biological Monograph and Manuals, 5: 130-131.

Hanson, C. H., Robinson, H. F. and Comstock, R. E., 1956. Biometrical studies of yield in segregating populations of Korean lespedeza L. Agronomy journal, 48(6), pp.268-272.

Johnson, H. W., Robinson, H. F. and Comstock, R. E. 1955. Estimates of genetic and environmental variability in soybean. Agronomy Journal, 47: 14318.

Kumar, N., Markar, S. and Kumar V. 2014. Studies on heritability and genetic advance estimates in timely sown bread wheat (Triticum aestivum L.).

Bioscience Discovery, 5(1): 64-69.

Lu, Q., Lillemo, M., Skinnes, H., He, X., Shi, J., Ji, F.,.. \& Bjørnstad, А. (2013). Anther extrusion and plant height are associated with Type I resistance to Fusarium head blight in bread wheat line 'Shanghai-3/Catbird'. Theoretical and applied genetics, 126(2), 317-334.

https://apps. fas.usda.gov /psclonline /circulars/production.pdf.

Lush J. L. 1945. Intrawire correlation or regression of offspring on dam as a method of estimating heritability of characteristics. 33 rd Annual Procedure of American Society for Animal Production. 293-301.

Nukasani, V., Potdukhe, N. R., Bharad, S., Deshmukh, S. and Shinde, S. M. 2013. Genetic variability, correlation and path analysis in wheat. Journal of Wheat Research, 5(2); 48-51.

Panse V. G. and Sukhatme P. V., 1954. Statistical Method for Agriculture Workers. Indian Council of Agricultural Research New Delhi, pp 381.

Singh R. K. and Chaudhary B. D. 1977. Biometrical Methods in Quantitative Genetic Analysis, Kalyani Publishers, New Delhi, pp 266. USDA (2019). United States Department of Agriculture.

Skinnes, H., Semagn, K., Tarkegne, Y., Marøy, A. G., \& Bjørnstad, A. (2010). The inheritance of anther extrusion in hexaploid wheat and its relationship to Fusarium head blight resistance and deoxynivalenol content. Plant Breeding, 129(2), 149-155.

Yadav, S. K., Singh A. K., Baghel, S. S., Jarman, M. and Singh, A. K. 2014. Assessment of genetic variability and diversity for yield and it's contributing traits among CIMMYT based wheat germplasm. Journal of Wheat Research, 6(2): 154- 159. 


\section{How to cite this article:}

Asha Kushwah, Sanjay Singh, Sushma Tiwari and Sikarwar, R. S. 2021. Evaluation of Genetic Variability, Heritability and Genetic Advance in Advanced Breeding Lines of Wheat (Triticum aestivum L). Int.J.Curr.Microbiol.App.Sci. 10(09): 531-537. doi: https://doi.org/10.20546/ijcmas.2021.1009.061 